\title{
THE USE OF THINK INSIDE THE BOX STRATEGY TO IMPROVE STUDENTS VOCABULARY MASTERY AT SECOND GRADE STUDENTS OF SMPN 4 PRAYA BARAT DAYA
}

\author{
Terasne $^{1}$, Nanag Sugianto ${ }^{2}$ \\ ${ }^{12}$ English Department, Fakulty of Education for English languge and Art of IKIP Mataram \\ terasne@yahoo.com
}

\begin{abstract}
The research is aimed to the use of think inside the box strategy be able to improve students vocabulary mastery. The subject of this study was 20 students at second grade students of SMPN 4 Praya Barat Daya. In which consist of 8 males and 12 females. It was classroom action research with two cycles, each cycles of four steps: planning, acting, observing and reflecting. The data gathering used written test, and questionnaires and analyzed by using quantitative and qualitative approach. At the result of the first cycle was failed where the mean score of pre test was 62.35 and class percentage was 30\% and he mean score of post test was 70.25 and class percentage was $65 \%$ and the result of the second cycle that the mean score was 80,2 and the class percentage was $80 \%$ indicating the target of 75 of the minimum criterion has been achieved, it means that the action was stopped.
\end{abstract}

Key Word: improve, vocabulary Mastery and Think Inside The Box.

\begin{abstract}
Abstrak
Penelitian ini bertujuan untuk mengetahui penggunaan strategi think inside the box untuk meningkatkan kosa kata siswa. Subjek dalam penelitian ini adalah 20 siswa kelas delapan di SMP N 4 praya barat daya. Yang mana terdiri dari 8 siswa laki laki dan 12 siswa perempuan. Ini merupakan penelitian tindakan kelas dengan dua siklus, setiap siklus memiliki 4 tahap: perencanaan, pelaksanaan, observasi, dan reflecting. Data yang di gunakan test tulis, dan angket. Dalam menganalisa data peneliti menggunakan pendekatan kuantitatif dan kualitatif. Hasil yang di peroleh dari siklus pertama adalah gagal di mana skor rata rata dari pre-test adalah 62,35 dan persentasi kelasnya $30 \%$ dan skor rata rata untuk post test adalah 70,25 dan persentasi kelasnya $65 \%$. Dan hasil untuk siklus yang ke dua nilai rata ratanya 80.2 dan persentasi kelasnya adalah $80 \%$ mengindikasikan dari target 75 dari pencapaian kriteria minimal, itu artinya pelaksanaan penelitian di hentikan.
\end{abstract}

Kata Kunci: improve, vocabulary Mastery and Think Inside The Box.

\section{INTRODUCTION}

\section{A. Background of the Study}

Vocabulary is one of element language in which must be mastered by all language learners, because without vocabulary someone cannot speak very well. According to Thornburry (2002: 1). Vocabulary is very useful in the process of building sentences; someone cannot speak and build sentences without mastering it. The English students who are lack of vocabularies will get difficult to speak to the others especially to a native speaker of a foreign language.

Based on statement above many students are still difficult to memorize word or vocabulary, they do not know the form of word, spelling the words, and the last is comprehend the meaning. In teaching vocabulary most of teacher just write the vocabulary in the whiteboard then students must remember it, but in this way many students bored and lazed. 
That problems also faced by the students of SMPN 4 Praya Barat Daya. The researcher tries to get percentages which pass the minimal score of mastery level criterion $(\mathrm{KKM})$, the mastery level criterion (KKM) is 75 which was adapted form school agreement. So researcher was used the new way of teaching vocabulary it is using "think inside the box" as strategy and supporting media that will make students more quickly to collect the word or vocabulary.

\section{B. Purpose of the study}

To describe whether the use of think inside the box strategy be able to improve students vocabulary mastery, at second grade students' of SMPN 4 Praya Barat Daya or not.

\section{Significances of the Study}

1. Theoretically

a. For school : The researcher hope that this strategy can become contribution and additional references for the school.

b. For researcher : The researcher hope that this strategy can become references for the next researcher.

2. Practically

a. For teacher : this strategy can always be used by the teacher in teaching and learning English process especially vocabulary.

b. For students : to give input for students to be able for mastering their vocabulary particularly in English vocabulary

\section{Scopes of the Study}

The scope of the study will discuses to the following points :

1. Subject

The subject of the study is the second grade of SMPN 4 Praya Barat Daya.

2. Object

This study will focus on think inside the box strategy to improving student vocabulary mastery at second grade students' of SMPN 4 Praya Barat Daya.

REVIEW OF RELATED LITERATURE

A. General Concept of Vocabulary

1. Definition of vocabulary

Jurnal Pendidikan Mandala
Vocabulary is one of language component, when we learning language, people also learn its components including vocabulary. Learning vocabulary is very important because vocabulary is one of the requirements for people to use language to communicate. Besides that, vocabulary is an important component to develop language. It is true that without vocabulary people cannot say anything.

2. Types of Vocabulary

When talking about vocabulary it is necessary to present the types of vocabulary as when one speaks to another we need some words to express his idea or desire, or when we listen, we must be able to catch the meaning. According to Schail Williams S.(1967: 57)

3. Indicator of Vocabulary According to Thornburry (002: 27) \& Brown (2003: 229) there are four indicators of vocabulary as follows:

a. Pronunciation

Research shows that words that are difficult to pronounce are more difficult to learn. Potentially difficult words will typically be those that contain sounds that are unfamiliar to some groups of learners such as regular or strength. Crisp or breakfast are also problematic.

b. Spelling

Sound spelling mismatches are likely to be the cause of errors, either of pronunciation or of spelling and can contribute to word difficulties. Where most English spelling is fairly low a binding. There are also some glaring irregular words containing silent letters that are particularly problematic: for example, foreign, listen, headache, climbing, bored, honest, cupboard, muscle, etc.

c. Meaning

When two words overlap in meaning, learners are likely confuse them. Make and do area case in point: you may breakfast and make appointment, but 
you do the housework and do a questionnaire and words which have multiple meanings such as since and still are also troublesome for learners. Having learned one meaning of the word, they may be reluctant to accept a second totally different meaning. Unfamiliar concepts may make words difficult to learn. Thus, culture specific items such as words and expressions associated with the game cricket (a sticky, a hat trick, a good innings) will seem fairly opaque to most learners and are unlikely to be easily learned.

d. Using words

The letter is most authentic, but even that askeded is constrained by a contrived station in which the test taker, usually in matter of seconds, has to come up with an appropriate sentence, which may not indicate that the test taker "knows" the word.

\section{B. Think inside the box}

According to Theodore Kinni (2013) Thinking inside the box constrains the brain's options and regulates how it produces ideas. By constraining and channeling our brains, we make them work both harder and smarter to find creative solution. there are some benefits doing thinking inside the box strategy. One of them is it help students to memorize the word quickly and internalize them. Students are not passive but active.

Steps of Teaching by Using Thinking Inside the Box

1. The teacher will divide students in a class into two groups equivalently, then The first group ( at least 10 students ).

2. The teacher will asked them to stand up and the teacher asked the student to guess what are inside the box, by the clue from the teacher.

3. The teacher will asked the students to pronounce those words and look for the meaning on the dictionary.

\section{RESEARCH METHOD}

\section{A. Research Design}

Jurnal Pendidikan Mandala
The research technique that was used in this research is Classroom Action Research (CAR) with Quantitative and Qualitative approach. Classroom action research begins with a question about classroom experience, issues and challenging. It is reflective process which helps teacher to explore and examine aspects of teaching learning and to take action to change and improve the students' achievement in teaching learning process.

This research consist of two cycles which each cycle consist of four steps are plan, action, observation, and reflection (kemmis and Mc Taggart, 1988: 11-14).

\section{B. Setting of the Research}

1. Place

this research was conducted in SMPN 4 Praya Barat Daya. It is located at Jln. Ungga - Ranggagata, Kecamatan Praya Barat Daya, Kabupaten Lombok Tengah West Nusa Tenggara Barat.

2. Time

This research was conducted from February to July 2016.

\section{Subject and Object of the Research}

1. Subject

The subject of this research was VIII A the second grade students' of SMPN 4 Praya Barat Daya. With 20 students and consist of 8 males and 12 females.

2. Object

The object of this research was think inside the box strategy to improve students vocabulary mastery at second grade students of SMPN 4 Praya Barat Daya.

\section{Instrument of The Research}

The research instrument is the tool or facility that can be used by researcher in activities to collect or setting the data to become systematic and make more easily (Arikunto, 2010:136). There are some instruments that will be use of this research as follow:

1. Test

The researcher was given the students multiple choice test, fill in the blank, and meaning test that consist of 25 items. Each 
item will be scored 1 if it's correct and 0 if it's incorrect.

2. Questionnaire

Questionnaires are conducted when the post-test are administrated to the students. The purpose is to see the students' opinion as well as their feeling during the learning activity.

\section{E. Procedures of the Research}

According to Kemmis (in Hopkin, 1985) action research along with the major steps, planning, acting, observing, reflecting.

1. Planning

The researcher prepared some instruments which is support in teaching learning process, such as material, lesson plan, steps in doing action, test items and questionnaire.

2. Acting

The researcher implemented the Classroom Action Research with the activities below :
a. Giving pre test
b. Teaching vocabulary by using think inside the box strategy
c. Giving post test
d. Questionnaire

3. Observing

Observation used to observe and note everything students' do in teaching learning process. The researcher will analyze the result of test to know whether the students' vocabulary improves or not.

4. Reflecting

Reflection is an activity in expressing of experience that have by teacher as the selfevaluation.

\section{F. Techniques of Data Collection}

Technique of data collection will be used is as follows:

1. Test

This research applied test to measure the student's ability in vocabulary. The test was consist of 25 items. In this test the researcher was uses multiple choice, fill in the blank, and meaning test to obtained the quantitative data.
2. Questionnaire

Questionnaire is divided and filled by students to know the students respond in process learning vocabulary by the application think inside the box strategy. This questionnaire is consists of five options by using Liker scale. According to Ridwan (2013: 87) there five categories of liker scale, such as: strongly agree (SS) the score is 5, agree (S) the score 4, don't know (TT) the score is 3, disagree (TS) the score is 2, and strongly disagree (STS) the score is 1 . The questionnaire test consists of 10 items.

\section{G. Techniques of Data Analysis}

1. Quantitative data

In analyzing the quantitative data, the researcher tried to get the average of students' vocabulary score per action in cycle. It was used how well students' performance during learning process of vocabulary. Second, the researcher tried to get the class percentage which passed the criteria of success that had been determined by the researcher is 75 (seventy five). It used the formula (Sudijono in Jaya, 2008: 43)

2. Qualitative data

Besides analyzing the result of the test and observing the activity during classroom Action Research, the researcher also uses questionnaire to find out students' response toward think inside the box strategy in learning vocabulary.

\section{H. Criteria of Car Success}

Classroom action research (CAR) is able to be called successful if it can exceed the criterion that has been determined by the researcher when there is $75 \%$ of students' achieve the target score or criterion of the school (KKM), and fail if it cannot exceed the criterion that has been determined by the school (KKM). In this study, thinking inside the box success in improving students' vocabulary when the students' can pass the target score 75.

RESEARCH FINDING AND DISCUSSION

\section{A. Research Finding}


The presentation of the result intends to answer the problems of investigation appear as formulated in previous chapter that "does the use of think inside the box strategy to improve students' vocabulary mastery at the second grade of SMPN 4 Praya Barat Daya This classroom action research was conducted two cycles from on $22^{\text {nd }}$ June to $28^{\text {th }}$ July 2016.

To find out the solution of these problems, the researcher intended to analyze the data obtained from the students' result and the students' activities in the class instead of any other result of research. The data was attained from the teaching learning process and evaluation. One of aimed of giving an evaluation was to know how far the students vocabulary mastery in this class room action research.

\section{B. Discussion}

After computing the data, the result of pre test was $62,35(30 \%)$, post test cycle 1 was $70,25(65 \%)$, and post test cycle 2 was 80,25 $(80 \%)$. The researcher can see the comparison between before and after teaching vocabulary by using think inside the box strategy. It means that think inside the box strategy, can improve the students vocabulary at the second grade students of SMPN 4 Praya Barat Daya. Most of the students could answer the test that given by the researcher after implementing think inside the box strategy in teaching vocabulary. The result of this data has answered the statement of the problem.

By looking the result of questionnaire above, it shows that most of the students like English and vocabulary lesson, because the percentage reaches out for $80 \%$. Then can be concluding that most of the students like when given game in their vocabulary class, based on the percentage that reach out for $80 \%$. About think inside the box was implemented in teaching vocabulary, most of the students is like about it, it was proven from the percentage that reach out for $90 \%$ and most of the students also like the topic of material used by think inside the box in their vocabulary class, it was proven from the percentage that reach out for $70 \%$.
Most of the students like teacher's was in giving think inside the box that given, the percentage reached $70 \%$. By implementing think inside the box strategy in teaching vocabulary, most of the students interesting in vocabulary lesson. It based on the percentage which reach out for $70 \%$. The vocabulary that used in think inside the box is easy to understand, it was proven by the percentage. There were $90 \%$ students that state it.

Proved that think inside the box has the advantage to improve students' vocabulary. It shows by the result of percentage was reach out for $75 \%$ from the students fell like that. And the last about meaning of vocabulary that given in think inside the box, it was proven by percentage was reach out for $70 \%$. The conclusion of them is, think inside the box strategy is effective used in teaching vocabulary to improve the students vocabulary mastery at the second grade students of SMPN 4 Praya Barat Daya. It can develop students in learning English, especially vocabulary.

\section{CONLUSION AND SUGGESTION}

This chapter is divided into two parts, conclusion and suggestion.

\section{A. Conclusion}

Think inside the box strategy effective used in teaching vocabulary to improve students' vocabulary mastery, it was proven by their response is very good, it based on the result of questionnaire which showed that more than $75 \%$ of the students are enthusiastic participate during the teaching learning process, and their scores between first cycle and second cycle was improved its proved by the result of the test, more than $80 \%$ of the students score of vocabulary mastery testis grater than or equal to 8 .

By using think inside the box strategy the students' vocabulary can improve, because by the using think inside the box in teaching vocabulary, the students was easily to remember the vocabulary that has been taught. It proven by the students score, in the final value, most of the students get 90 point in doing the tasked. 
About the students response to the think inside the box it used by the teacher in teaching vocabulary are: all of the students were happy and interested in the use if this strategy. Most learners pointed out that it was very useful to make easier remember the vocabulary for them. During teaching and learning process the students gave good responses towards the use of think inside the box. This can be seen from their active participation and enthusiasm in teaching learning process.

\section{B. Suggestion}

After getting the result of the study in this research, the writer would like to give some suggestions as follows:

1. For the Teachers

In order to improve the students vocabulary and to make the teaching learning process more fun and can be taught well, the researcher suggests for all the English teacher, improving students 'think inside the box strategy' was suitable to implemented to all students, it aims to avoid the students boredom and improve students English vocabulary.

2. For the Students

The students should use the think inside the box strategy with their friend as medium to improve their vocabulary mastery.

3. For the Readers

Readers could know the vocabulary mastery be using think inside the box strategy at the second grade students of SMPN 4 Praya Barat Daya. Especially, the students of English department of IKIP Mataram.

4. For the writer

The writer would get knowledge in vocabulary mastery by using think inside the box strategy, the writer would know difficulties faced by the students in vocabulary mastery and offer some possible solution.

\section{REFERENCES}

2014. Statistika untuk Penelitian.

Alpabeta: Bandung
Harmer.1991. The Practice of English Language Teaching. London: Longman.

Haycraft , 1978. An Introduction to English Language Teaching. England: Longman Group.

Heaton, J.B.1990. Writing English Language Test. London and New York: Longman Group.

Hiebert, H. elfrieda and Michail L. Kamil. 2005. The Teaching and Learning of Vocabulary. London: Lawrence Erlbaum Associated (LEA).

Kemmis, S \& Mc Taggart. 1998. The Action Research Planner. Victoria: Deakin University

McCarten, Jeanne. 2007. Teaching Vocabulary. New York: Cambridge University Press.

Nation, I.S.P. 2000. Learning Vocabulary in another Language. Cambridge: Cambridge Applied Linguistics

Nobert Schamit and Michael, Mc. Chartey. 1997. Vocabulary; Description, Acquisition, and Pedagogy. United Kingdom: Cambridge University Press.

Purwanto, Ngalim. M. 2010 EvaluasiPengajaran. Bandung: PT. RemajaRosdaKarya

Rebecca L. Oxford. 1990. Language Learning Strategies. Boston: Heinle Publisher

Schiering, Marjorie S., Drew Bogner, and Jorun Buli-Holmberg. 2011. Teaching and Learning: a Model for Academic and Social Cognition.Rowman \& Littlefield Education. United Kingdom.

Slavin E Robert. 1995. Cooperative Learning Theory Research and Practice.Bostom: Allin and Bacon.

Sugiyono. 2014. Metode Penelitian Pendidikan. Bandung: Alfabeta.

Suharsimi

Arikunto.2010.

MetodePenenlitianPendidikan: Bandung:

Alfabeta 
Theodore Kinni. 2013. Thinking Inside the Box http://www.strategy-

business.com/blog/Thinking-Inside-

the-Box?gko=97ad9 Accessed on Monday 15 of February 2016.

Thornbury, Scott. 2002. How to Teach

Vocabulary. London: Longman Group.

Ur, Penny. 1996. A Course in Language

Teaching Practice and Theory.

Cambridge: Cambridge University

Press. 